Article

\title{
Prospero, the Divine Shepherd, and Providence: Psalm 23 as a Rubric for Alonso's Redemptive Progress and the Providential Workings of Prospero's Spiritual Restoration in Shakespeare's The Tempest
}

\author{
David V. Urban \\ English Department, Calvin University, Grand Rapids, MI 49546, USA; dvu2@calvin.edu
}

Received: 16 June 2019; Accepted: 18 July 2019; Published: 24 July 2019

\begin{abstract}
In this essay, I argue that Psalm 23 serves as a thematic rubric through which to understand how Prospero's machinations affect the progress of the redemption of King Alonso throughout the play. At the same time, however, recognizing Prospero's moral complexities and deficiencies, I also argue that Prospero's mercy toward and reconciliation with Alonso ultimately demonstrates the sovereign influence of a Providence beyond Prospero's control—a Providence that works through charity and grace beyond Prospero's initial intentions. This higher providential power, therefore, ought rightly to be seen as the ultimate shepherd of the play-one who works to affect not only Alonso's but also Prospero's spiritual restoration.
\end{abstract}

Keywords: The Tempest; Bible; Providence; Prospero; Alonso; Ariel; Caliban; Epilogue; Richard Hooker; John Calvin; Twelfth Night; Malvolio; Gonzalo

Studies on Shakespeare's use of the themes and language from the Bible have flourished since the beginning of the twentieth century, continuing to the present day. ${ }^{1}$ However, no critic has yet investigated Shakespeare's use of Psalm 23 in his late romance, The Tempest. In this essay, however, I will argue that Psalm 23 serves as a thematic rubric through which to understand how Prospero's machinations affect the progress of redemption of King Alonso throughout the play. (Readers will recall that Alonso-now shipwrecked with his royal company by Prospero's magic on the island Prospero rules-supported then-Duke Prospero's usurpation by his brother, Antonio). I suggest that Shakespeare's text demonstrates, in ways that Alonso himself never recognizes and in ways that transcend Prospero's own understanding, that Prospero's supernatural orchestration of various events-particularly his preventing Alonso's murder and his spectacular but ultimately merciful prodding of Alonso's conscience in ways that elicit the king's repentance and restoration-allows Shakespeare's audience to view Alonso in relation to the psalm's speaker and to view Prospero in relation to the psalm's Lord and shepherd.

At the same time, however, recognizing Prospero's own moral deficiencies-his problematic penchant for complete control over the persons and events of the play, his deep-seated bitterness against his enemies, and, indeed, his own need for redemption-in this essay, I will also argue that Prospero's mercy toward and reconciliation with Alonso ultimately demonstrates the sovereign influence of a Providence beyond Prospero's control—a Providence that works through charity and grace beyond Prospero's initial intentions, a Providence that transcends the efforts of any human individual, however powerful and however benevolent or flawed, who would seek to exercise godlike machinations even

1 See especially (Shaheen 1999), (Hamlin 2013), and, very recently and for the Special Issue "Religions in Shakespeare's Writings," (Skwire 2018) and (Stelzer 2019). 
within his limited sphere of control. This higher providential power, therefore, ought rightly to be seen as the ultimate shepherd of the play-one who works to affect not only Alonso's but also Prospero's spiritual restoration in ways that also recall aspects of Psalm 23.

My essay, on one level, falls within the long tradition of viewing Prospero as a kind of God figure upon his island, although my recognition of Prospero's various moral shortcomings distinguishes my reading of Prospero from the more idealized views offered by (Russell 1876, pp. 482-85), (Still 1921, pp. 202-3), or (Boitani 2013, pp. 89-123). ${ }^{2}$ Nonetheless, I argue that Prospero's basic attitude toward Alonso is benevolent, seeking genuine reconciliation with the man largely responsible for exiling Prospero and his daughter Miranda, desiring the restoration of Alonso's soul. ${ }^{3}$ In this sense, Prospero plays the role of the divine shepherd of Psalm 23, and we may trace the path of Alonso's redemption through Prospero's benevolent (albeit also self-interested) machinations by comparing certain stages of Alonso's time on the island with specific portions of the psalm. I will note that certain specific connections between the psalm and the play are ironic in nature, but when we view these connections within the larger process of Alonso's redemption, we may recognize that these ironic elements play significant roles within Alonso's redemptive progress. Finally, in this essay, I shall demonstrate that the goodness and mercy that pursue Alonso throughout the play transcend Prospero's intentions toward Alonso-intentions that combine both benevolence and a bitterness that wars against Prospero's better virtues. Indeed, our recognition that a higher benevolence than Prospero's guides the paths of Alonso's and Prospero's redemptions allows us to better understand Prospero's complexities as one who, amid his own godlike control of the events and persons who surround him, is in the end a fallible human being also needing forgiveness. ${ }^{4}$

\section{Psalm 23, Prospero, and Alonso's Redemptive Progress}

I quote Psalm $23^{5}$ in full below:

1 The Lord is my shepherd, I shal not want.

2 He maketh me to rest in grene pasture, \& leadeth me by the stil waters.

3 He restoreth my soule, \& leadeth me in the paths of righteousnes for his Names sake.

4 Yea, thogh I shulde walke through the valley of the shadow of death, I wil feare no euil: for thou art with me: thy rod and thy staffe, they comfort me.

5 Thou doest prepare a table before me in the sight of mine aduersaries: thou doest anoint mine head with oyle, and my cup runneth ouer.

6 Douteles kindenes, \& mercie shal follow me all the dayes of my life, and I shal remaine a long season in the house of the Lord.

Throughout my discussion, I do not argue that the stages of Alonso's Prospero-guided progress of redemption occur in an order that coincides with the order of the psalm's verses; however, each of the verses expresses an idea or action that, in some way, significantly coincides with Prospero's restoration of Alonso. ${ }^{6}$ The psalm's first verse establishes both Prospero's essential godlike benevolence toward Alonso and a basic assurance that, whatever his hardships on Prospero's island, Alonso will be cared for by his merciful host. The sixth and final verse similarly establishes the mercy and grace with

2 See also (Knight 1948, pp. 208, 232, 234, 242) and (Nuttal 1957, pp. 6-7, 9-10).

3 Robert Egan states that Prospero's intentions in shipwrecking the royal party are to subject Alonso (and, ideally, Antonio and Sebastian as well) "to an ordeal of self-knowledge and purgation" (Egan 1972, p. 175).

4 My reading of Prospero as one whose intentions toward his enemies are genuinely restorative but nonetheless significantly tainted by morally problematic emotions and actions goes against the portrayal of Prospero as primarily manipulative and self-serving as seen in (Shakespeare 1987), although I do not thereby deny the appropriateness of some of Orgel's skepticism about Prospero's character.

5 This and all biblical quotations, unless otherwise noted, are from the 1560 Geneva Bible (Geneva Bible 1969).

6 My extensive use of Psalm 23 as a rubric by which to understand The Tempest finds some precedent in (Esolen 1997) and its extensive use of Isaiah as a key for understanding the same play. 
which Prospero pursues Alonso-a grace that offers blessings that extend well beyond the temporal parameters of the play. The verses in 23.2-5 suggest specific ways in which Prospero's benevolence toward Alonso manifests itself.

Psalm 23.2 parallels rather explicitly Prospero's machinations toward Alonso in Act 2, Scene 2, even as Psalm 23.6 is implicitly present here and in the other scenes where Alonso is present. Although of course ignorant of the source of the benevolence that now "follow[s]" them, Alonso's councilor, Gonzalo, immediately recognizes Prospero's "mercie" toward the king's party. As the party-consisting also of the evil Antonio, Alonso's treacherous brother Sebastian (who also supported Prospero's usurpation), and the young lords Adrian and Francisco-walks, presumably not far from the now "stil waters" from which they emerged, Gonzalo observes the "miracle" of their "preservation" (2.2.6-7), noting not only that they are all alive upon a verdant island but also the strange fact that their recently sea-drenched garments are unstained and in excellent condition. Specific parallels with Psalm 23.2 are evident in lines 189-98, when Alonso, along with the other voyagers besides Antonio and Sebastian, are made to rest, indeed sleep, by Prospero's magic via Ariel. This rest is a great mercy indeed to Alonso, whose soul —not to mention body—is painfully weary because of the presumed drowning of his son, Ferdinand. Significantly, the grass in which they lie down is described by Gonzalo as "lush and lusty" and "green" (2.2.53-54), and Gonzalo's description recalls the "grene pasture" of Psalm 23.2, in which the psalm's speaker proclaims that the Lord "maketh me rest." When Ariel awakens Alonso and Gonzalo just in time to foil Antonio and Sebastian's attempt to murder them, we see Psalm 23.4 come into view. For although Alonso "walke[s] through the valley of the shadow of death" (or sleeps there!), he need "feare no euil," because Prospero is with him through Ariel, with Prospero's magic "staffe" protecting the king. ${ }^{7}$

When Alonso next appears in Act 3, Scene 3, we again see him "walke through the valley of the shadow of death" in ways that he himself does not recognize. He again complains of his weariness and hopelessness because of Ferdinand's supposed death (3.3.5-10), and we may rightly suspect that he now contemplates suicide; more explicitly, however, Antonio and Sebastian remain resolved to murder Alonso and Gonzalo (3.3.11-17). However, amid Alonso's danger, Prospero is there-explicitly present "on the top" of the stage and "invisible" to the other human characters, ${ }^{8}$ as is described by the stage directions following line 17-protecting the king with his magic staff in ways that I shall discuss below.

It is just at this point that Prospero's spirits bring forward their banquet table, and here the play's connection to Psalm 23-specifically verse 5-again becomes explicit: Prospero here "prepare[s] a table before me [Alonso] in the sight of my aduersaries." At this point, the ironic nature of the play's connection to Psalm 23 is increasingly significant. For although Prospero does indeed prepare a banquet table for Alonso in the presence of his unknown-to-him enemies and would-be murderers, the table disappears before they can eat of it, and any blessing Prospero here offers the hungry king is not immediately apparent. Such blessing is even less apparent when, upon the table's disappearance, Ariel appears as a harpy—a mythical bird "associated with guilt and punishment" (Kott 1976, p. 433)—to

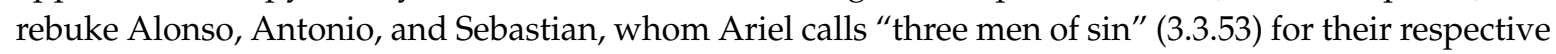
roles in Prospero's usurpation and, says Ariel, Prospero's and Miranda's drowning. Ariel also specifically tells Alonso that because of divine justice, his own son has also been drowned:

$$
\text { ... for which foul deed }
$$

The pow'rs, delaying, not forgetting, have

7 Unless otherwise noted, all quotations for The Tempest are from (Shakespeare 1999). A more cynical reading of this scene is offered by Curt Breight, who suggests that "Prospero is responsible for setting up [Antonio and Sebastian's] conspiracy," the knowledge of which Prospero uses at the end of the play "to blackmail" the duo (Breight 1990, p. 16). I rather suggest that, in this scene, Prospero uses Ariel's ministrations to test Antonio and Sebastian, finding them unchanged in their morality from twelve years earlier.

8 In a comment germane to the present study, John C. Adams describes Prospero here as appearing “like some god of Olympus surveying mortals on the earth" (Adams 1938, p. 415). 
Incensed the seas and shores, yea, all the creatures,

Against your peace. Thee of thy son, Alonso,

They have bereft; and do pronounce by me

Ling'ring perdition (worse than any death

Can be at once) shall step by attend

You and your ways... (3.3.72-79)

One might object at this point that the table that Prospero prepares for Alonso hardly resembles the image of blessing, protection, and spiritual refreshment suggested by Psalm 23.5. However, Ariel's speech, though it initially torments the guilt-stricken Alonso, is intended "to reform" (Lamb 1998, p. 544). At the end of his terrifying speech, Ariel offers an alternative to "Ling'ring perdition": "heart's sorrow" (repentance) that brings about "a clear [innocent] life" (3.3.81-82). ${ }^{9}$ Indeed, Ariel's confrontation becomes a wondrous instrument of grace to affect the king's redemption, and when Prospero, describing Ariel's speech, says, "a grace it had" (3.3.84), he speaks better than most commentators recognize. As Grace Tiffany recognizes, Ariel "has 'grace'" and "is a heavenly hound who drives" sinners "to repentance" (Tiffany 2000, p. 429). Indeed, the "table" that Prospero prepares for Alonso "in the sight of" his enemies is a table that confronts sin and offers spiritual cleansing. ${ }^{10}$ Moreover, both Alonso's mournful admission of his transgression against Prospero and his recognition of the consequent (seeming) drowning of Ferdinand (3.3.95-99, which I examine closely later) clearly distinguish him from the thoroughly unrepentant responses of Antonio and Sebastian, who exit after senselessly declaring their intentions to battle the supernatural forces they are powerless to oppose (3.3.103-4). Significantly, their shocked reactions to Ariel's speech have displaced their plot to murder Alonso-a displacement attributable to Prospero's machinations. Nonetheless, we should note that Alonso's final words in the scene are not hopeful:

Therefore my son $\mathrm{i}^{\prime}$ th' ooze is bedded; and

I'll seek him deeper than e'er plummet sounded

And with him there lie mudded. (3.3.100-2)

Here, Alonso declares his frankly suicidal intention, but he does not act on his despair. Rather, the next time we see Alonso is early in the play's final scene (stage instructions following 5.1.57). There, he enters with Sebastian and Antonio, as well as Gonzalo, Adrian, and Francisco, all charmed by Prospero's spell, unable to speak, and seemingly unable to move but by Ariel's leading, presumably taken captive by Ariel at Prospero's behest shortly after the party's exit at the end of Act 3, Scene 3 . Here, we can see that Prospero has again protected Alonso as he "walke[s] through the valley of the shadow of death," for Alonso has been harmed neither by Antonio and Sebastian nor by himself.

When Prospero breaks his charm and restores Alonso and the others to their senses, Alonso, who had been described as entering the scene "with a frantic gesture," responds immediately to Prospero's self-revelation with both relief and humble, tangible repentance as he speaks to his former captor:

Thy pulse

Beats, as of flesh and blood; and, since I saw thee,

$\mathrm{Th}^{\prime}$ affliction of my mind amends, with which,

I fear, a madness held me... .

$\ldots$

9 My glosses upon "heart's sorrow" and "clear" are taken from Peter Holland's notes in (Shakespeare 1999, p. 59). Perhaps more helpfully, Maurice Hunt defines "heart's sorrow, / And a clear life ensuing" as "repentance and sanctification" (Hunt 1993, p. 294). Thomas McAlindon correctly observes that here, Alonso has "been subjected to an experience designed by Prospero to lead him through 'heart's sorrow' to 'a clear life ensuing' (III.iii.81-2)" (McAlindon 2001, p. 348).

10 Anthony M. Esolen, following the reading of (Berger 1977, pp. 226-27) that Ariel's banquet table "is eucharistic," argues that the sinful trio's unconfessed sin prevents them from eating at the table. Indeed, "There can be no communion ... without repentance" (Esolen 1997, p. 233). 
Thy dukedom I resign and I do entreat

Thou pardon me my wrongs. (5.1.113-16, 118-19)

Alonso's plea for Prospero's forgiveness ${ }^{11}$ is accompanied by his report that his afflicted mind has been healed, presumably by the opportunity to gain reconciliation with the man for whose supposed death the conscience-stricken Alonso knew he was responsible. Here, we see that Prospero's machinations have again brought about another specific and spiritually crucial element of Psalm 23: the psalmist's declaration that the Lord "restoreth my soule" (23.3), with the soul encompassing both the emotional and moral dimensions that Alonso describes above. Moreover, Alonso's stated intention to return Milan's dukedom to Prospero-who introduces himself to Alonso as "The wronged Duke of Milan, Prospero!" (5.1.107)—demonstrates that Prospero is successfully leading Alonso "in the paths of righteousness for his Names sake" (Psalm 23.3). Indeed, Prospero's self-interest in Alonso's redemptive progress is captured within the psalm as well, for Alonso's repentance affirms the truth of Prospero's naming himself the rightful Duke of Milan.

However, the blessings that Prospero here offers Alonso go beyond forgiveness and moral/spiritual restoration; indeed, Prospero blesses Alonso in ways that exceed the king's hopes, thus coinciding with another portion of Psalm 23. We must recognize that, even after Alonso and Prospero are reconciled, Alonso remains convinced that Ferdinand is drowned, expressing his resignation to this supposed fact: "Irreparable is the loss, and patience / Says it is past her cure" (5.1.140-41). Moreover, when Prospero tells him that he also "lost [his] daughter" (5.1.148), Alonso responds by uttering a seemingly unanswerable prayer for the two youths and then expressing his desire to die in their stead:

O heavens, that they were both living in Naples,

The king and queen there! That they were, I wish

Myself were mudded in that oozy bed

Where my son lies. (5.1.149-52)

Prospero soon proceeds to present the still-living and now-engaged Ferdinand and Miranda to Alonso, who responds with joy and amazement (see 5.172-215). Remarkably, what Prospero now gives Alonso transcends even the king's stated fantasy: Alonso had wished that the couple could be ruling in Naples, at the price of his own life; but now, his wish has been granted beyond his utterance, for Alonso is separated from Ferdinand and his bride neither by death nor by location, and they have every expectation to live together happily back in Naples for years to come. Alonso's joy in his "discovery that [his] despairing prayer is to be answered" is repeated in his "ecstatic" "amen" (5.1.204) to Gonzalo's benediction upon the young couple (5.1.201-4) (McAlindon 2001, p. 347). The fact that Prospero here blesses Alonso in ways that transcend the king's deepest hopes again reflects Psalm 23, in which the psalmist proclaims, "my cup runneth ouer" (23.5). Moreover, Alonso's overflowing blessings increase upon the sudden reappearance of the Boatswain, who joyously announces that their ship, which they thought had been destroyed, is now miraculously "tight and yare and bravely rigged as when / We first put out to sea" (5.1.224-25), having been secretly repaired by Ariel at Prospero's direction.

Having examined specific parallels between portions of The Tempest and particular phrases in Psalm 23.2-5, let us now return to the larger thematic parallels between Alonso and Prospero's relationship and Psalm 23.1 and 23.6, particularly the latter. In light of Prospero's arranging of the presumably happy and fruitful marriage between Ferdinand and Miranda, we recognize that Prospero's "kindenes \& mercie" will pursue Alonso "all the dayes of [his] life." Indeed, Alonso's delight in the couple's engagement suggests that their marriage and anticipated children will indeed bless Alonso for the remainder of his years.

11 Francis Neilson notes that Alonso's "remorse" and "confession" follows the pattern of "the Lord's Prayer" (Neilson 1959, p. 430). 
Moreover, Prospero's charity toward Alonso is evident throughout the entire play, for the opening scene suggests Prospero's first effort to "restore" Alonso's "soule" (23.3). We see little of Alonso in the first scene, but what we hear about him is extremely important: amid the tempest, Gonzalo announces that "The king and prince [are] at prayers," urging the others to "assist them, for our case is as theirs" (1.1.52-53). In stark contrast to Alonso, Antonio and Sebastian show no interest in prayers, even as their lives seem almost certain to end, and Antonio continues to heap abuse upon the Boatswain, to whom he has recently said, "We [he and Sebastian] are less afraid to be drowned than thou art" (1.1.44-45), displaying a startling degree of self-righteousness for a fratricide at death's door. Significantly, from the onset of the play, Alonso behaves very differently from Prospero's other enemies, recognizing his own mortality and his need to make peace with the divine before his death.

If Alonso is "at prayers" during the first scene's tempest, we may speculate regarding the content of his prayers. Given that the passengers recognize their imminent deaths as almost inevitable, we may expect that Alonso here offers prayers of confession, asking for forgiveness of past sins. The play's text suggests both that the praying Alonso is remembering his sin against Prospero and that Prospero himself is orchestrating this recollection. The evidence for this assertion can be found in Alonso's response to Ariel's speech to the "three men of $\sin ^{\prime \prime}$ :

$\mathrm{O}$, it is monstrous, monstrous!

Methought the billows spoke and told me of it,

The winds did sing it to me, and the thunder,

That deep and dreadful organ pipe, pronounced

The name of Prosper; it did bass my trespass. (3.3.95-99)

The immediate context of these lines suggests that the "billows," "winds," and "thunder" that Alonso mentions are those that accompany Ariel's speech (McAlindon 2001, p. 348), which the stage directions tell us is accompanied by "Thunder and lightning" and, arguably, the "loud winds" and "still-closing waters" that Ariel mentions when he tells Alonso, Sebastian, and Antonio the following:

The elements,

Of whom your swords are tempered, may as well

Wound the loud winds, or with bemocked-at stabs

Kill the still-closing waters, as diminish

One dowl that's in my plume. (3.3.61-65)

Robert Grams Hunter goes so far as to assert that Alonso's "memory of his crime against Prospero [had] sunk to the bottom of his mind" until Ariel's speech (Hunter 1965, p. 232).

However, the idea that Alonso would not have considered—during what he thinks are his final prayers before death!- - his role in the presumed deaths of Prospero and Miranda seems highly unlikely. Rather, Alonso's diction suggests that his above lines also, or even primarily, refer to the initial tempest of the opening scene. Indeed, For Alonso to say "Methought the billows spoke ... " with reference to Ariel's speech seems odd on several levels. First, because Ariel's speech ends only seconds before Alonso speaks, "Methinks" would be the more appropriate word choice if Alonso were referring to this speech. However, "Methought" is entirely appropriate if Alonso is referring back to what he thought he heard in the initial tempest. Second, the word "methought" implies that Alonso has some uncertainty about what he just heard concerning Prospero and his sin against him. However, what Ariel, fully visible in the form of a harpy, has just spoken is abundantly clear, both to Alonso and the others, so any expression of uncertainly by Alonso regarding Ariel's speech seems out of place. Such uncertainty, however, is entirely understandable if, during the opening scene's tempest, an invisible Ariel spoke to the king of his sin against Prospero. Moreover, Alonso's presumed prayers of confession in the opening scene are a sensible response to such foreboding words.

Third and closely related to the previous point, Alonso here speaks of hearing of such matters from the "billows," "winds," and "thunder." However, although Shakespeare's stage directions explicitly 
mention that "thunder and lightning" precede (and perhaps accompany) Ariel's speech, Ariel's convicting words are clearly spoken by Ariel, not the elements. However, an invisible Ariel speaking of Alonso's sin during the opening tempest would certainly give the impression that such words were being spoken by the elements themselves. Fourth, again closely related, is Alonso's mention of the "billows" speaking. Although Ariel talks of "still closing waters" in his speech, the stage directions do not mention them, and Ariel's words do not necessarily mean that such threatening waters are near them at this time. However, such billows were certainly present during the tempest.

Finally, Alonso's declaration that the thunder "did bass my trespass" merits scrutiny. Why does Alonso say "my trespass" instead of "our trespass," given the fact that Ariel clearly addresses all three transgressors in his speech? Obviously, Alonso is, at this point, consumed with the horrible realization that his sin has brought about the seeming death of his son, and perhaps that is explanation enough. However, the idea of having the thunder specifically speak of Alonso's trespass is especially sensible if Ariel, invisible during the tempest, spoke to Alonso individually. In that case, Alonso would already be conscience stricken before he commenced to prayers beneath the ship's hull, and indeed, Ariel's words would have elicited Alonso's determination to pray. Moreover, and related to my first point two paragraphs above, Alonso's saying "did bass"—as opposed to "bassed"—again serves to remove from this scene's immediate temporal context Ariel's initial supernatural declaration of Alonso's sin against Prospero. Moreover, "did bass" also allows for the possibility of the actor playing Alonso to emphasize the word "did" —an emphasis that would affirm Alonso's previous sense that the thunder during the opening scene's tempest did in fact "pronounce / The name Prosper" and thus "bass [Alonso's] trespass." All this textual evidence suggests that Alonso's ultimately grace-giving conviction of sin, elicited by Prospero via Ariel, began upon the ship during the initial tempest.

\section{Prospero, Providence, and the Path to Redemption}

In this essay thus far, I have demonstrated both that Psalm 23 offers an important interpretive rubric by which to understand Alonso's redemptive progress and that Prospero's active work eliciting Alonso's progress is evident from the play's opening scene, manifesting itself in each scene in which Alonso appears and climaxing during the final scene. For the remainder of the essay, I will move beyond direct discussion of Prospero's efforts in Alonso's redemption and investigate how the play's larger redemptive structure suggests the workings of a greater Providence that guides the action of the play as well as events in Prospero's life that precede the play's action. This Providence transcends Prospero's machinations-be they benevolent or self-serving-and indeed precipitates not only Alonso's but also Prospero's redemption in ways that again call to mind Psalm 23, as we perceive Providence working through both to protect Alonso and Prospero from death and to restore their souls, a restoration that culminates in the play's final scene and Prospero's Epilogue. Throughout this section, while not denying my previous assertions regarding Prospero's ultimately restorative intentions toward Alonso, I will emphasize somewhat Prospero's moral imperfections, recognizing his own need for spiritual restoration amid the conflict that rages within Prospero's soul, as he vacillates between his desires for reconciliation and vengeance.

The play's first suggestion of such a Providence is explicitly mentioned in the second scene. There, after Prospero tells Miranda his account of his betrayal and usurpation at the hands of his beloved brother Antonio, with Alonso's support, Miranda asks, "How came we ashore?" Prospero immediately responds, "By Providence divine" (1.2.159-60). ${ }^{12}$ The argument that Prospero's words ought to be considered a genuine acknowledgement of divine aid is strengthened by Prospero's previous description of the unseaworthy boat that his usurpers provided him and Miranda in the hope that they would drown at sea. He calls it:

A rotten carcass of a butt, not rigged,

12 My capitalization of "Providence" follows (Shakespeare 1974) and various other editions. 
Nor tackle, sail, nor mast; the very rats

Instinctively have quit it. (1.2.146-48)

Moreover, Prospero's description of the sea's initial condition when he and Miranda were placed in the boat is significant: "There they hoist us, / To cry to th' sea that roared to us" (1.2.148-49). However, likely alluding to the Providence he explicitly mentions moments later, Prospero continues: "to sigh / To the winds, whose pity, sighing back again, / Did us but loving wrongs" (1.2.149-51). ${ }^{13}$ Indeed, although Prospero's enemies put Prospero and Miranda into a wretched boat in adverse conditions, the winds themselves, guided "[b]y Providence divine," modulated the roaring sea, took them-similar to the psalm's speaker- "through the valley of the shadow of death" (23.4a), and brought them safely to the island where they lived twelve years. Providence is also evident in the ministrations of then-three-year-old Miranda, who, Prospero tells her, was, during their sea journey, "a cherubim / ... that didst preserve me ... / Infuséd with a fortitude from heaven" (152-54). ${ }^{14}$ Prospero's recollection of Miranda's angelic blessings again parallels the sentiment of the psalmist, who tells his Lord, "for thou art with me: thy rod and thy staffe, they comfort me" (23.4b).

The hand of Providence is also implicitly evident in Prospero and Miranda's ability to live on the island for many years. Prospero immediately follows his mention of providence by noting the gracious efforts of Gonzalo, who, "Out of his charity" (emphasis added; we may note Prospero's theologically rich diction here, cf. 1 Corinthians 13), stocked the boat with "food," "fresh water," "garments," and various other "necessaries," as well as Prospero's books (1.2.162, 160, 164; see 160-68). Indeed, in spite of his deadly situation, Prospero, thanks to Gonzalo's charity, did "not want" (Psalm 23.1). The items Gonzalo gave Prospero enabled him and Miranda to survive their trip and initial days on the island, even as they enabled Prospero to free Ariel from the "cloven pine" (1.2.277) where he was trapped for twelve years by the spell of the witch Sycorax (see 1.2.277-79). We may speculate whether the "art" (1.2.291) Prospero used to free Ariel was a magic spell from his books or simply the wielding of an ax Gonzalo might have included among the aforementioned "necessaries" (see 1.2.291-93). Indeed, we may see the hand of Providence in providing Prospero and Miranda with the assistance of Caliban, who, upon their initial encounters, "showed the[m] all the qualities o' th' isle" (1.2.337). Conversely, we may ask whether Prospero's decisions to enslave Ariel and eventually Caliban mark Prospero's violation of these providential provisions in favor of misusing his powers to lord his authority over others. We may not unreasonably speculate that Ariel would have happily assisted Prospero out of gratitude instead of compulsion, as Caliban happily assisted Prospero when he first befriended him. In any event, I suggest that Prospero's decision to enslave the two beings whom Providence provided to assist him marks Prospero's transition away from righteous dependence on the good shepherd to his morally problematic penchant for controlling others, which characterizes his rule of the island.

It is beyond the scope of this essay to discuss at length the significant moral violations evident in Prospero's enslavement-and, at least in the case of Caliban, consistently harsh treatment-of Ariel and Caliban. ${ }^{15}$ However, we ought to note that Prospero's extreme control of Ariel and Caliban seems motivated by expedience over morality-a practice ironically similar to Antonio's self-justification for usurping Prospero's dukedom. Significantly, it is within his exercise of extreme control that we meet Prospero and see him in action for the vast majority of the play, and amid this exercise of control, Prospero's word choice reveals a disinclination to recognize the Providence that works above his own efforts.

13 James Walter asserts that these lines allude to "a Spirit at work in the very processes of nature and history" (Walter 1983, p. 71).

14 McAlindon writes that "Providence operated first through Gonzalo ... and secondly, through Miranda herself, who was to her despairing father what the comforting angel was to the storm-tossed Paul" (McAlindon 2001, p. 340).

15 Intriguing recent commentary on this topic is offered by Julia Reinhard Lupton, who writes that Prospero fails to grasp a proper "natural law perspective" that could show him his "equality with Caliban in both dignity and sin," even as he "negate[s] the emancipatory potential of natural law and instead wield[s] the rhetoric of nature to justify slavery" (Lupton 2019, p. 9). 
Prospero's movement away from acknowledging Providence displays itself promptly in his conversation with Miranda. After Miranda asks his "reason" (1.2.175) for causing the tempest, Prospero replies:

Know thus far forth.

By accident most strange, bountiful Fortune

(Now, my dear lady) hath mine enemies

Brought to this shore; and by my prescience

I find my zenith doth depend upon

A most auspicious star, whose influence

If now I court not, but omit, my fortunes

Will ever after droop. (1.2.176-84)

Significantly, and in marked contrast to his statement only minutes before, Prospero here offers no credit to the Christian notion of Providence for the remarkable development of his enemies' ship passing so close the island but, rather, cites to the pagan notion of "Fortune" - a word choice that calls to mind the absurd mutterings of the vain and deceived steward Malvolio in Twelfth Night who, contemplating the notion that his rich and beautiful mistress, the Countess Olivia, might indeed love him, says, "Tis but fortune, all is fortune" (2.5.23) ${ }^{16}$ a parallel that casts some suspicion on Prospero's character. Prospero's change in diction is noteworthy in that Shakespeare's contemporary Christian audience would likely have considered Alonso's ship's unexpected proximity to the island to be as providential as Prospero and Miranda's safe arrival upon its shore. However, Prospero's rhetoric moves away from such an interpretation. Boasting of his "prescience" and speaking within the context of his own "raising" of the tempest that brought his enemies to his island, he declares his pursuit of another pagan symbol of destiny-a "most auspicious star," which he must actively "court" lest his "fortunes" forever "droop." Remarkably, Prospero's reference to this star again parallels the words of Malvolio, who, reading Olivia's maid Maria's forged letter that he thinks reveals Olivia's love for him, ridiculously proclaims, "I thank my stars ... . Jove and my stars be prais'd!" (2.5.170, 172-73). Though Prospero's words lack the "astrological determinism" (Hunt 1993, p. 281) evident in Malvolio's, Prospero's diction in this paragraph and its accompanying self-exaltation suggest that his portrayal of the supernatural here is on some level as wrongheaded as that of the duped and self-deceived Malvolio-a man who, in the words of Olivia, is characterized by "self-love" (1.5.90).

It is instructive to consider Prospero's aforementioned word choices in light of theological writings contemporary to Shakespeare on the topic of Providence. As Hunt observes, according to the Church of England's most influential theologian, Richard Hooker (1554-1600), "What is Providence to God, working His will through secondary natural agents, goes ... by different names among men" (Hunt 1993, p. 286). "Nature," writes Hooker in Of the Laws of Ecclesiastical Polity, "is nothing else but God's instrument" (Hooker 1841, p. 211). He also writes:

Only thus much discerned, that the natural generation and process of all things receiveth order of proceeding from the settled stability of divine understanding. This appointeth unto them their kinds of working; the disposition whereof in the purity of God's own knowledge and will is rightly termed by the name of Providence. The same being referred unto the things themselves here disposed by it, was wont by the ancient to be called natural Destiny. (Hooker 1841, p. 211)

Additionally, John Calvin (1509-1564), in his Institutes of the Christian Religion, writes:

Basil the Great has truly said that "fortune" and "chance" are pagan terms, with whose significance the minds of the godly ought not to be occupied. For if every success is God's

16 The quotations from Twelfth Night are from (Shakespeare 1974). 
blessings, and calamity and adversity his curse, no place now remains in human affairs for fortune or chance .... I see that men have a very bad custom, that where one ought to say "God willed this, they say, "fortune willed this." ... [Augustine] sufficiently demonstrates that men are under, and ruled by, providence. (Calvin 1960, pp. 207-8)

As Hooker asserts, though the ancients might use the term "Destiny" - a term we shall soon see used by Prospero via Ariel—any such workings by natural effects are properly termed God's Providence. Calvin's language is stronger, admonishing the godly not to credit "fortune" with what is in fact God's Providence. We may recognize that Calvin's aforementioned words cast an even more absurd light upon Malvolio who-though he is, in Maria's words, "sometimes ... a kind of a puritan" (2.3.139) and thus should presumably heed Calvin's words-attributes his life's developments to pagan forces. Prospero, of course, makes no pretense to puritanism. Yet, in light of Hooker's and Calvin's words and Prospero's strange parallels to Malvolio, we may recognize something religiously problematic about Prospero's movement away from acknowledging divine Providence. ${ }^{17}$ This movement coincides with his assertion of control over the natural and the supernatural-an assertion that complicates his spiritual condition even as he continues to orchestrate his "project" (5.1.1) that affects the lives of every person on the island.

Notably, Prospero concludes his aforementioned speech by magically putting Miranda to sleep, punctuating his act by saying, "I know thou canst not choose" (186). Prospero's magical control over his daughter-a control exhibited again in his conversation with Ariel that directly follows-helps explain his choice against giving Providence credit for Alonso's ship's proximity to the island. Twelve years before, the betrayed and victimized Prospero, in the throes of a fratricidal usurpation and expected to die at sea, was utterly dependent upon the "charity" of Gonzalo and the "Providence divine" that modulated the weather and brought him and Miranda safely ashore. (That Prospero's worldview when arriving at the island was still basically Judeo-Christian is also suggested by Caliban when he tells Prospero, "When thou cam'st first, / Thou ... / . . / . . [did] teach me how / To name the bigger light, and how the less, / That burn by day or night" [1.2.332-33, 334-36], an obvious allusion to Genesis 1.16.) However, now Prospero's seemingly complete control of his surroundings, a control brought about by his mastery of magic and consequent power over Ariel and the other spirits of the island, allows him to even control the weather and manipulate the actions of his usurpers and the others on their ship. Prospero's use of magic, though clearly abetted by the magic of the isle itself and often used for ostensibly benevolent purposes, certainly alters his spiritual perspective. ${ }^{18}$ The fact that sorcery is explicitly condemned within the occult "abominations" of Deuteronomy 18:9-14 ${ }^{19}$ suggests some explanation for Prospero's movement away from a more Christian framework in order to understand his present situation and his relationship to the events at hand. Nonetheless, even if Prospero chooses not to acknowledge the workings of Providence in bringing his enemies near his shore, Shakespeare's "Jacobian audience" would recognize "the stirring of God's hand" (Tiffany 2000, p. 435;

17 In light of the documented influence of the book of Isaiah upon The Tempest (Esolen 1997), Prospero's pagan diction recalls the 1610 Douay-Rheims Bible's translation of Isaiah 65:11: "And you, that haue forsaken the Lord, that haue forgotten my holie mount, that set a table for fortune ... " (Douay-Rheims Bible 1635). This translation appeared just before or during the time Shakespeare wrote The Tempest, generally held to be 1610-11.

18 Egan asserts that the "assumption of godlike powers and responsibilities by one [Prospero] who is in no way superhuman" brings about "the central problem of the play," for Prospero's powers, "being capable of great evil as well as great good, place him in a perilous position." Egan notes, "We need only remind ourselves that "prospero" is the Italian for "faustus" (Egan 1972, p. 175). Anthony Harris argues that Prospero, by finally abjuring his "rough magic" (5.1.50), admits "the damnable nature of his art" (Harris 1980, p. 136). One need not go as far as Harris (see [Cornfield 1985] for a more moderate position) to recognize that Prospero's mastery of magic and control of spirits leaves him less dependent on the Judeo-Christian concept of providence. John D. Cox suggests that recognizing the parallels between Prospero's and Shakespeare's art-particularly with reference to Prospero's bewildering claim to have raised the dead (5.1.48-50)—defuses the notion that Prospero exercised "demonic power" (Cox 2007, p. 214).

19 See particularly Deuteronomy 18:10 and 14, which specifically forbid "sorcerer[s]"; note also that Caliban describes Prospero to Stephano as "A sorcerer" (3.2.43). 
Calvin 1960, p. 210) in orchestrating their arrival-an arrival that paves the way for the restoring of not only Alonso's but also Prospero's soul.

Prospero's rhetorical preference for a pagan presentation of life's unfolding is again evident in the previously discussed scene in which the disguised Ariel confronts Alonso, Antonio, and Sebastian. Significantly, Ariel begins his speech as follows:

You are three men of sin, whom destiny-

That hath to instrument this lower world

And what is in't- the never-surfeited sea

Hath caused to belch up you ... (3.3.53-56, emphasis added)

A bit later, as the company attempt to draw their swords, Ariel says, "You fools: I and my fellows / Are ministers of Fate" (3.3.60-61, italics added). Ariel's speech was dictated by Prospero, who, invisible, watches the scene and says to Ariel "Of my instruction has thou nothing bated / In what thou hadst to say" (3.3.85-86). Ariel's use of the words "destiny" and "Fate" are especially important here. Although earlier I emphasized the spiritually restorative nature of Ariel's speech, we now ought to recognize that here Prospero-even as he offers through Ariel's words what Hooker might consider a paganized nod toward a larger providential design — does not actually credit a Providence beyond himself. Rather, unbeknownst to Ariel's listeners, Prospero implicitly portrays himself as "destiny" and "Fate," as well as "The pow'rs" who, because of the trio's "foul deed" against Prospero and Miranda, have now "Incensed the seas and shores, yea, all the creatures, / Against your peace" and have specifically "bereft" Alonso "of [his] son" (3.3.73, 72, 74-75, 76, 75). Indeed, Prospero, through his sorcery, is playing God here, assuming the role of divine justice even as he misleads and tortures Alonso with false information regarding Ferdinand, and although the effects of this scene ultimately bring Alonso to repentance, we may rightly question Prospero's benevolence here and ask if his intentions at this point are in fact reconciliation with his enemies or, rather, the dubious satisfaction of vengefully watching them suffer at his hands. He glories in his victory over his oppressors, saying, "My high charms work, / And these, mine enemies, are all knit up- / In their distractions: they now are in my pow' $r^{\prime \prime}$ (3.3.88-90). His words here do not reflect Psalm 23's divine shepherd. Viewing Prospero in the fullness of his character and recognizing the conflict between his benevolent intentions and his lingering bitterness, we may see the godlike Prospero for what he is: a man who, as may be expected of a victim of betrayal, is torn between a longing for reconciliation and a desire for vengeance. ${ }^{20}$

Yet, providentially, Prospero's efforts bring about a good that transcends the bitterness that mitigates his charity. Indeed, if we may cynically suggest that, on one level, Prospero's initial words regarding Ariel's speech—“a grace it had, devouring" (84)—speak ironically from Prospero's immediate perspective concerning the "grace" one says before "devouring" a meal, ${ }^{21}$ we understand, nonetheless, that Ariel's words do indeed work grace to restore Alonso's soul, convicting him of sin and leading to the repentance and reconciliation of the play's final scene. Moreover, even if the acts of nature on and near the island have been and are being directly orchestrated by Prospero, Alonso himself "apprehends Providence through its secondary agent, nature" (Hunt 1993, p. 295), which not only speaks the name of Prospero and exposes Alonso's sins but has also worked to wreck his ship and seemingly drown Ferdinand as belated justice for Alonso's crimes. Nonetheless, we must recognize that, if this scene were left only to Prospero's own design, Alonso's restoration might never have come about. Strikingly, Alonso's final words in this scene declare his intention to commit suicide, not pursue forgiveness. Convinced that Ferdinand is drowned, Alonso declares, "I'll seek him deeper than e'er

20 R. A. D. Grant writes that "Prospero's residual and quite understandable resentment and tetchiness prior to the great forgiveness scene do not qualify or diminish his goodness, but are rather a constant reminder of what must be conquered or sublimated in order to achieve it" (Grant 1983, p. 241). Grant's comment is easier to agree with in light of the whole of the completed play than at the moments when Prospero, in his resentment, tortures others and even endangers another's life, as he does here. I would add that Prospero's overall goodness has been tainted by his treatment of Caliban.

21 Holland's notes for (Shakespeare 1999) indicate that here "devouring" means "making the banquet disappear" (p. 59). 
plummet sounded / And with him there lie mudded" (3.3.101-2). In addition, Prospero in this scene indicates no desire for restoration. ${ }^{22}$ Rather, in exiting, he states, "And in these fits I leave them ... " (3.3.91), departing before Alonso speaks his horrified words.

It is not Prospero but, rather, Gonzalo who, providentially, works here to save Alonso from self-destruction in this "valley of the shadow of death." ${ }^{23}$ Seeing that Alonso, Antonio, and Sebastian "are desperate" because of "their great guilt" (3.3.104), Gonzalo, once again displaying "grace" (Grant 1983, p. 249), beseeches his younger companions to "follow them swiftly / And hinder them from what this ecstasy / May now provoke them to" (3.3.107-9). Here, as in his saving of Prospero and Miranda twelve years earlier, Gonzalo-who has just before inquired of Alonso "in the name of something holy" (3.3.94)—acts with charity toward Alonso and the others, recognizing their emotional and spiritual desperation and the potential deadliness of their situation. Although Antonio and Sebastian here pursue violence toward others, Gonzalo correctly discerns Alonso's danger of self-harm. Although Ariel presumably works Prospero's charm on the king's company not long after the scene's end, Alonso's being alive at that point can be credited to Gonzalo and the workings of a Providence that transcends whatever charity Prospero intended to grant Alonso amid Ariel's speech. ${ }^{24}$ Indeed, the restoring of Alonso's soul in this scene works itself out both through and beyond Prospero's actions.

As the play's final scene begins, Prospero is still reveling in his power and the success of his plans. His repeated use of the word "my" suggests his focus. He concluded the penultimate scene by declaring to Ariel, "At this hour / Lies at my mercy all mine enemies" (4.1.262-63), and he opens the final scene by telling him, "Now does my project gather to a head. / My charms crack not, my spirits obey ... " (5.1.1-2). At this point, however, Ariel's words break into Prospero's self-focus and control, challenging him to consider the condition of those who now stand "at [his] mercy" and to move toward compassion and genuine mercy:

The king,

His brother, and yours abide all three distracted,

And the remaining mourning over them,

Brimful of sorrow and dismay; but chiefly

Him that you termed, sir, the good old Lord Gonzalo.

His tears runs down his beard like winter's drops

From eaves of reeds. Your charm so strongly works 'em,

That if you now beheld them, your affections

Would become tender.

PROSPERO

ARIEL

Mine would sir, were I human. (5.1.11-20)

Prospero's response to Ariel's prodding is to empathize with his captives' sufferings, bid Ariel to "release them," and commit to "restore" "their senses" (5.1.30, 31). He states, "They being penitent, / The sole drift of my purpose doth extend / Not a frown further" (5.1.28-30; see 20-32). Upon Ariel's exit, Prospero also vows to "abjure" his "rough magic" and to "break [his] staff" and "drown [his] book" (5.1.51, 50, 54, 57; see 33-57). After Ariel returns with Alonso and his company, all still under Prospero's charm, a deeply emotional Prospero speaks his forgiveness to his oppressors and promises

22 Hunt writes, "For the moment, Prospero's eagle-like desire for vengeance overwhelms his angelic, Christian intentions" (Hunt 2003, p. 227).

23 Grant correctly asserts that Gonzalo "is in his limited way a direct human representation of the Providential power that lies behind the play." He "imitate[s]" and "embodie[s] the action of Providence" (Grant 1983, p. 249).

24 The observation by Tiffany concerning Pericles and The Winter's Tale, that "it is not human rituals but God's grace, working through Providential time, that effects resolution and miracles" (Tiffany 2018, p. 2), is applicable to The Tempest, especially as we read "human rituals" as signifying Prospero's imperfect machinations. 
to Ariel to free him presently (5.1.58-87). Renouncing vengeance and illegitimate forms of control, Prospero enters into the risks of relationships as he prepares to return to Italy.

Hunt has written persuasively about Ariel's role as "a grace-giving Spirit" in this scene, noting that Ariel's words "providentially" provoke "a Christian-like pity within Prospero" (Hunt 2013, p. 65). Hunt goes on to discuss the theological importance of Ariel's prompting Prospero to empathy:

Empathy for another's suffering, especially in association with forgiveness, is notably a principle of Judeo-Christian doctrine. Generally humankind's emulation of a deity whose compassion and forgiveness for humankind is singular moves men and women to the conversion Prospero experiences. (Hunt 2013, p. 66)

In any event, if Prospero's original intention toward Alonso was, from the initial tempest in the opening scene, to prod his conscience and offer him the opportunity for repentance, it has been threatened by Prospero's flirtation with vengeance and his exultation in seeing the suffering of his erstwhile oppressors, demonstrating within himself "an ambivalence that would seem well to be described in Romans 7" (Cox 2000, p. 39). ${ }^{25}$ Ariel's words prompting Prospero to forgiveness and reconciliation come providentially from without, acting to restore Prospero's soul, offering a shepherding guidance, and eliciting but not demanding Prospero's change of heart. ${ }^{26}$ Having "deftly exposed" Prospero's "moral gaps," "Ariel offers a contingent vision of Prospero's better self, opening a gap into which Prospero can choose to step" (Gibbons 2017, pp. 326, 327).

With Prospero's own decision to respond with charity in mind, we ought to briefly consider another spiritually restorative decision in Act 5 and its influence on Prospero. We have already discussed at length Alonso's decision to repent for his wrongs against Prospero-a decision that, significantly, he makes before Prospero reveals to him that Ferdinand is living and engaged to Miranda. By contrast, Antonio and Sebastian, also objects of Prospero's charity and forgiveness, decidedly reject their opportunities for repentance and reconciliation. However, perhaps most significant in light of the play's remarkable Epilogue is Caliban's repentance before Prospero after he and his spirits foil Caliban and his newfound associates, Stephano and Trinculo, in their pathetic attempt to murder Prospero. Responding to Prospero's merciful requirement that he merely clean Prospero's cell in order to gain his "pardon," Caliban replies, "Ay, that I will; and I'll be wise hereafter, / And seek for grace" (5.1.295-96). Caliban's confession—significantly, something that is not under his master's control—is most remarkable in that it ironically provides an example of repentance that Prospero will soon imitate. For if Ariel's gentle challenge has prompted Prospero's Christlike empathy and forgiveness, Caliban's desperate plea for mercy exemplifies what Prospero must do to obtain reconciliation with the Providence he sought to displace amid his practice of complete control. Indeed, even as Antonio's callous refusal to repent demonstrates for Prospero the ultimate limitations of supernatural power to coerce another's free will, Prospero's own clemency toward Caliban, coupled with his implicit admission of longstanding wrongdoing against his slave- “ this thing of darkness I / Acknowledge mine" (5.1.275-76)—elicits a declaration of repentance rich in theological significance. Strikingly, Caliban couples his resolution to "seek for grace" with a renouncing of the pagan worldview that sought

25 See Romans 7:7-26, especially Romans 7:21: “ . . when I wolde do good, euil is present with me.” Hunt writes that Prospero is "conflicted by his desire to both destroy and to forgive his enemies" (Hunt 2013, p. 63). Although I suggest that Prospero's intentions from his initial conjuring of the tempest incline toward benevolence, Hunt's statement well captures the internal moral warfare that takes place within the mind of one whose recollections of his betrayal and usurpation have tortured his mind for the past twelve years.

26 Prospero's decision to renounce vengeance here, Alonso's and Caliban's subsequent decisions to repent, Antonio's and Sebastian's decisions not to repent, and, certainly, Prospero's final repentance during the Epilogue all speak to Barbara Kiefer Lewalski's observation that the English church contemporary to Shakespeare, in its modified Calvinism, "reserve[d] some role, however ambiguously stated, for human response to divine grace" (Lewalski 1979, p. 20). (Hunt 1993) and (Hunt 2004) apply the perspective of Hooker's and other English divines' "centrist Reformational theology" (Smith 2018, p. 3) to Shakespeare's plays. 
to manipulate his surroundings through his worship of the "dull fool" and "drunkard" Stephano, whom he took for his " $\operatorname{god}^{\prime}(5.1 .298,297){ }^{27}$

In his deeply theological Epilogue that immediately follows his freeing of Ariel, Prospero, now utterly bereft of the magic spells and the command of spirits that allowed him to control the island, freely admits that his remaining "strength" is but "mine own" and "is most faint" (Epilogue 2-3). Without his magic and spirits, Prospero is no more a god than Stephano, and he would himself be a "dull fool" were he to depend on his own power. Yet, providentially, Prospero's "cup runneth ouer" with spiritual guidance from a most unlikely source who aids in his soul's restoration into "the paths of righteousness" (Psalm 23.3). Similar to Caliban, Prospero must himself now turn away from any pretense of a pagan manipulation of Fortune and, similar to Caliban, seek grace. ${ }^{28}$ His most spiritually meaningful words, replete with "Christian overtones" (Hunt 2013, p. 69), ${ }^{29}$ conclude the play:
And my ending is despair
Unless I be relieved by prayer,
Which pierces so that it assaults
Mercy itself and frees all faults.
As you from crimes would pardoned be,
Let your indulgence set me free. (Epilogue 15-20)

Much can be said regarding the "specifically Christian significance" (Cox 2000, p. 39) of these lines, and John D. Cox rightly observes that the Epilogue's final couplet "urges a specifically Christian response to Prospero based on the fourth petition of the Lord's Prayer: 'Forgiue vs our dettes, as we also forgiue our detters (Matt. 6:12)" (Cox 2000, p. 40; cf. Esolen 1997, p. 247). Indeed, in these lines the once-spiritually isolated Prospero reenters the community of the faithful, seeking grace as he begs the audience's charity through spiritual intercession. However, for the purposes of this essay, we do well to emphasize Prospero's request that he be "relieved by prayer" so fervent that "it assaults / Mercy itself." Prospero's use of the word "Mercy" as metonymy for the Christian God recalls to us the final verse of Psalm 23 and its speaker's promise that "kindenes, \& mercie shal follow me all the dayes of my life." Prospero's humble appeal to Mercy here stands in stark contrast to his previous self-glorying boast: "At this hour / Lies at my mercy all mine enemies" (4.1.262-63, italics mine). As we consider the workings of Providence in Prospero's life throughout The Tempest, we may suggest that Prospero, having renounced his religion of paganized self-sufficiency, now understands his need to pursue the Mercy that has been, beyond his recognition, pursuing him. ${ }^{30}$

Funding: This research received no external funding.

Acknowledgments: This essay recently developed out of work begun years earlier during a sabbatical leave. I deeply thank Calvin University for its support.

Conflicts of Interest: The author declares no conflict of interest.

27 Discussing the role of Providence in The Tempest, Lois Feur writes that the play does not depict "passive humanity, led by a puppet-master," but rather "human and divine actions conjoining to produce the final, benevolent result" (Feur 1997, p. 281). Considering optimistically Ferdinand and Miranda's future life in Naples, Brian Sutton writes that "the play suggests that Prospero's earlier misfortunes were part of a larger divine plan" for Alonso's and Prospero's "descendants" (Sutton 2008, p. 228).

28 As Tiffany observes, in Shakespeare's late romances, "Human participation in God's comedy requires characters to turn away from 'pagan' works to Christian faith" (Tiffany 2018, p. 2). The respective efforts to "seek for grace" that we see in Act 5 and the Epilogue by Alonso, Caliban, and Prospero recall Matthew J. Smith's recent suggestion that "Shakespeare unites his characters through patterns of action ... that demonstrate a shared experience of religion as a desire for salvation beyond the law" (Smith 2018, p. 2).

29 Prospero's Epilogue has been examined from different theological perspectives within Christianity. (Tiffany 2000, p. 439) suggests Calvinist dimensions, whereas (Beauregard 1997) and (Beauregard 2008, pp. 145-56) argue at length for its Catholic underpinnings. Following the basic thrust of (Hunt 2004), I believe that an understanding of Shakespeare's apparent sympathy for the "middle way" of Richard Hooker's theology can allow us to profit from both Tiffany's and Beauregard's arguments.

30 My reading of Prospero's supplication stands in stark contrast to the skeptical reading offered by (Sanchez 2008, p. 81). 


\section{References}

Adams, John C. 1938. The Staging of The Tempest, III.iii. The Review of English Studies 14: 404-19.

Beauregard, David N. 1997. New Light on Shakespeare's Catholicism: Prospero's Epilogue in The Tempest. Renascence 49: 159-74.

Beauregard, David N. 2008. Catholic Theology in Shakespeare's Plays. Newark: Delaware University Press.

Berger, Karol. 1977. Prospero's Art. Shakespeare Studies 10: 211-39.

Boitani, Piero. 2013. The Gospel According to Shakespeare. Translated by Vittorio Montemaggi, and Rachel Jacoff. Notre Dame: University of Notre Dame Press.

Breight, Curt. 1990. "Treason Doth Never Prosper": The Tempest and the Discourse on Treason. Shakespeare Quarterly 41: 1-28.

Calvin, John. 1960. Institutes of the Christian Religion. Edited by John T. McNeill. Translated by Ford Lewis Battles. Philadelphia: Westminster Press, vol. 1.

Cornfield, Cosmo. 1985. Why Does Prospero Abjure His “Rough Magic"? Shakespeare Quarterly 36: 31-48.

Cox, John D. 2000. Recovering Something Christian about The Tempest. Christianity and Literature 50: 31-51.

Cox, John D. 2007. Seeming Knowledge: Shakespeare and Skeptical Faith. Waco: Baylor University Press.

Douay-Rheims Bible. 1635. Available online: https://archive.org/details/1610A.d.DouayOldTestament1582A.d. RheimsNewTestament_176 (accessed on 8 July 2019).

Egan, Robert. 1972. This Rough Magic: Perspectives of Art and Morality in The Tempest. Shakespeare Quarterly 23: 171-82.

Esolen, Anthony M. 1997. "The Isles Shall Wait for His Law": Isaiah and The Tempest. Studies in Philology 94: 221-47.

Feur, Lois. 1997. Happy Families: Repentance and Restoration in The Tempest and the Joseph Narrative. Philological Quarterly 76: 271-87.

Geneva Bible. 1969, In A Facsimile of the 1560 Edition. Madison: University of Wisconsin Press.

Gibbons, Daniel R. 2017. Inhuman Persuasion in The Tempest. Studies in Philology 114: 302-30.

Grant, R. A. D. 1983. Providence, Authority, and the Moral Life in The Tempest. Shakespeare Studies 16: $235-63$.

Hamlin, Hannibal. 2013. The Bible in Shakespeare. Oxford: Oxford University Press, vol. 1.

Harris, Anthony. 1980. Night's Black Agents: Witchcraft and Magic in Seventeenth-Century Drama. Manchester: University of Manchester Press.

Hooker, Richard. 1841. The Works of that Learned and Judicious Divine, Mr. Richard Hooker, 2nd ed. Edited by John Keble. Oxford: Oxford University Press, vol. 1.

Hunt, Maurice. 1993. Malvolio, Viola, and the Question of Instrumentality: Defining Providence in Twelfth Night. Studies in Philology 90: 277-97.

Hunt, Maurice. 2003. Visionary Christianity in Shakespeare's Late Romances. CLA Journal 47: 212-30.

Hunt, Maurice. 2004. Shakespeare's Religious Allusiveness: Its Play and Tolerance. Aldershot: Ashgate.

Hunt, Maurice. 2013. Shakespeare's The Tempest and Human Worth. The Ben Jonson Journal 20: 58-71.

Hunter, Robert Grams. 1965. Shakespeare and the Comedy of Forgiveness. New York: Columbia University Press.

Knight, G. Wilson. 1948. The Crown of Life: Essays in Interpretation of Shakespeare's Final Plays. London: Methuen \& Co.

Kott, Jon. 1976. The Aeneid and The Tempest. Arion: A Journal of Humanities and the Classics 3: 424-51.

Lamb, Mary Ellen. 1998. Engendering the Narrative Act: Old Wives' Tales in The Winter's Tale, Macbeth, and The Tempest. Criticism 40: 529-53.

Lewalski, Barbara Kiefer. 1979. Protestant Poetics and the Seventeenth-Century Religious Lyric. Princeton: Princeton University Press.

Lupton, Julia Reinhard. 2019. The Tempest and Black Natural Law. Religions 10: 91. [CrossRef]

McAlindon, Thomas. 2001. The Discourse of Prayer in The Tempest. SEL: Studies in English Literature 1500-1900 41: 335-55.

Neilson, Francis. 1959. Shakespeare and The Tempest, XII. The American Journal of Economics and Sociology 18: 429-32.

Nuttal, A.D. 1957. Two Concepts of Allegory. New York: Barnes and Noble.

Russell, Edward R. 1876. The Religion of Shakespeare. The Theological Review 13: 459-85.

Sanchez, Melissa E. 2008. Seduction and Service in The Tempest. Studies in Philology 105: 50-82.

Shaheen, Naseeb. 1999. Biblical References in Shakespeare's Plays. Newark: University of Delaware Press. 
Shakespeare, William. 1974. The Riverside Shakespeare. Edited by G. Blakemore Evans. Boston: Houghton Mifflin. Shakespeare, William. 1987. The Tempest. Edited by Stephen Orgel. Oxford: Clarendon.

Shakespeare, William. 1999. The Tempest. Edited by Peter Holland. The Pelican Shakespeare. New York: Penguin. Skwire, Sarah. 2018. Curse, Interrupted: Richard III, Jacob and Esau, and the Elizabethan Succession Crisis. Religions 9: 331. [CrossRef]

Smith, Matthew J. 2018. "At War "Twixt Will and Will Not": On Shakespeare's Idea of Religious Experience in Measure for Measure. Religions 9: 419. [CrossRef]

Stelzer, Emily E. 2019. Lear, Luke 17, and Looking for the Kingdom Within. Religions 10. forthcoming.

Still, Colin. 1921. Shakespeare's Mystery Play: A Study of "The Tempest." London: Cecil Palmer.

Sutton, Brian. 2008. "Virtue Rather Than Vengeance": Genesis and Shakespeare's The Tempest. The Explicator 66: 224-29.

Tiffany, Grace. 2000. Calvinist Grace in Shakespeare's Romances: Upending Tragedy. Christianity and Literature 49: 421-45.

Tiffany, Grace. 2018. Paganism and Reform in Shakespeare's Plays. Religions 9: 214. [CrossRef]

Walter, James. 1983. From Tempest to Epilogue: Augustine's Allegory in Shakespeare's Drama. Publications of the Modern Language Association of America 98: 60-76.

(C) 2019 by the author. Licensee MDPI, Basel, Switzerland. This article is an open access article distributed under the terms and conditions of the Creative Commons Attribution (CC BY) license (http://creativecommons.org/licenses/by/4.0/). 